\title{
Kesenian Tradisi Reog Sebagai Pembentuk Citra Ponorogo
}

\author{
Dhika Yuan Yurisma', Agung EBW²\&Agus Sachari ${ }^{3}$ \\ ${ }^{1}$ Program Studi Magister Desain Institut Teknologi Bandung \\ e-mail:dhikayuanyurisma@gmail.com \\ ${ }^{2}$ Program Studi Magister Desain Institut Teknologi Bandung \\ e-mail: agungebw83@yahoo.com \\ ${ }^{3}$ Program Studi Magister Desain Institut Teknologi Bandung \\ e-mail: @gmail.com
}

\begin{abstract}
Abstrak.Manunggale Cipto, Roso, Karso Agawe Rahayuning Bumi Reog slogan ini terpampang pada Pendopo Agung Ponorogo yang terletak di alun-alun pusat Kota Ponorogo. Ponorogo memanfaatkan kesenian tradisonalnya yaitu Reog untuk mengkomunikasikan kotanya. Reog merupakan kesenian khas daerah Ponorogo yang telah ada sejak berabadabad yang lalu dan diwariskan secara turun-temurun di kalangan masyarakat Ponorogo hingga saat ini. Kesenian ini juga banyak mengandung tradisi dan nilai-nilai luhur budaya yang harus dilestarikan, untuk itu pemerintah mengangkat Reog sebagai inspirasi dalam menciptakan sebuah brand bagi kotanya. Reog dihadirkan melalui berbagai elemen pembentuk citra kota, tujuan utama dari pencitraan ini adalah mengundang hadirnya para wisatawan domestik maupun asing, terutama pada acara tahunan yang diadakan oleh pemerintah yaitu Grebeg Suro.

Penelitian ini menggunakan pendekatan kualitatif dengan metode penggalian data melalui observasi dan wawancara. Penggalian data dilakukan selama empat hari di Ponorogo untuk mengetahui citra kota yang dihadirkan melalui Reog. Analisis citra kota ditinjau berdasarkan hasil wawancara terhadap masyarakat dan pengunjung Kota Ponorogo.

Hasil penelitian menunjukan adanya paradoks yang terjadi pada Reog ketika digunakan sebagai pembentuk citra kota Ponorogo. Citra kota yang dihasilkan tidak sesuai dengan makna secara tradisi yang terkandung pada Reog Ponorogo.
\end{abstract}

Kata kunci:Reog, city branding, citra kota, Ponorogo,

Abstract. Manunggale Cipto, Roso, Karso Agawe Rahayuning Bumi Reog this slogan plastered on Ponorogo Great Hall, located in the central square of the city Ponorogo. Ponorogo utilize tradisonalnya art that reog to communicate his city. Reog a typical art Ponorogo region that has existed since centuries ago and passed down from generation to generation among the people of Ponorogo until today. This art also contains a lot of traditions 
and noble values of culture that must be preserved, for it is the government raised reog as inspiration in creating a brand for the city. Reog presented through the various elements forming the image of the city, the main purpose of this imaging is to invite the presence of domestic and foreign tourists, especially at the annual event organized by the government, namely Grebeg Suro.

This study used a qualitative approach with the method of extracting data through observation and interviews. Data mining conducted over four days in Ponorogo to know the city's image is presented through reog. City image analysis are reviewed based on interviews of the community and visitors to the City Ponorogo.

The results showed the existence of paradox that occurs in reog when used as an image-forming Ponorogo city. The resulting image of the city is not in accordance with the meaning traditionally contained in reog Ponorogo.

Keywords:Reog, city branding, city image, Ponorogo,

\section{Pendahuluan}

Citra menjadi sesuatu yang penting dalam mengembangkan sebuah kota, membentuk identitas kota, dan menambah daya tarik kota. Citra kota yang spesifik dan kuat akan membentuk identitas yang kuat dari kota tersebut sehingga memiliki daya tarik yang positif. Citra dan identitas kawasan seakan telah menjadi tolak ukur bagi kualitas suatu lingkungan khususnya menyangkut cara pandang orang terhadap nilai lingkungan tersebut (Lynch, 1982). Individu mengalami reaksi terhadap lingkungan fisik bangunan dan perkotaan yang mereka lihat, reaksi tersebut menjadi pengalaman berupa citra (image) lingkungan yang tersimpan dalam ingatan, dan kemudian citra inilah yang akan mempengaruhi perilaku.

Terkait dengan pemanfaatan Reog sebagai inspirasi city branding Ponorogo, adalah salah satu upaya dalam melestarikan budaya lokal. Reog telah menjadi satu dengan masyarakat Ponorogo, keduanya sudah tidak dapat terpisahkan keberadaannya. Penyebutan Reog Ponorogo juga tidak terlepas dari usaha pemerintah dalam memanfaatkan asset yang mereka miliki sebagai media dalam memasarkan daerahnya. Reog dan Ponorogo merupakan satu tidak dapat dipisahkan, meskipun keduanya berbeda akan tetapi kedua kata tersebut saling mengikat satu sama lain.

Ponorogo mengusung slogan Manunggale Cipto, Roso, Karso Agawe Rahayuning Bumi Reog slogan ini terpampang pada pendopo agung yang terletak di alun-alun Kota Ponorogo. Ponorogo mengangkat kesenian tradisional sebagai sumber inspirasicity brandingyang dilakukan. Hal ini juga bisa terlihat pada logo Kabupaten Ponorogo yang menggunakan salah satu karakter dalam pementasan Reog Ponorogo. Pada logo tersebut terlihat jelas penampang Reog dibelakang gambar gapura, selain itu pembangunan gapura-gapura sebagai pintu masuk ke Ponorogo, serta patung- 
patung yang menghiasi di setiap simpul jalan utama, semuanya terinspirasi dari Reog Ponorogo.

Menurut Murfianti (2010) city branding banyak digunakan oleh kota-kota dunia dalam upaya meningkatkan atau merubah citra suatu tempat/wilayah/kota, dengan menonjolkan kelebihan dan keunikan daerah tersebut. Salah satu tujuan dari pemerintah Ponorogo selain untuk menjaga kelestarian kesenian tradisonal, tentunya Ponorogo ingin merepresentasikan kotanyamelaluiReog.

Menurut Anholt salah satu pendekataan dalam membentuk sebuah identitas kota yaitu melalui kebudayaan kota tersebut. Setiap kota pastinya memiliki sejarah masing-masing. Bagi beberapa, sejarahnya panjang dan luar biasa, sementara lainnya pendek tetapi tetap menarik. Setiap kota mempunyai hikayat untuk diceritakan tentang dasar dan pembangunannya, warga negara terkenal, artis dan momen berarti. Sering kali hal-hal tersebut disimbolkan dengan landmark kota seperti arsitektur bangunan, teater, stadion, museum, tempat umum, monumen, dan fitur alami.

Dalam kajian tentang desain sebagai bahasa rupa,desain dianggap sebagai alat komunikasi aneka macam gagasan atau ide. Reog ponorogo merupakan sebuah desain yang digunakan sebagai inspirasicity brand Ponorogo maka dari itu desain Reogadalah objek kajian spesifik yang perlu ditelaah lebih lanjut untuk mengetahui alasan bagaimana Reog mencitrakan Ponorogo. Selain menghadirkan suatu karakter, kesenian tradisional ini memuat pesan lain yang tersampaikan pada benak masyarakat. Kesenian Reog Ponorogo hadir tidak semata untuk keindahan belaka. Demi keperluan city branding kesenian tradisional ini dapat juga menyisipkan pesan lain, bahkan isu kontroversial, sehingga diterima dimasyarakat sebagai hal yang umum.

Melihat penjabaran diatas, maka pertanyaan utama dari penelitian iniadalah bagaimana Reog mencitrakan Ponorogo? Melihat latar belakang dan rumusan permasalahdiatas, maka tujuan dari penelitian ini adalahmemahami peran kesenian tradisional dalam membentuk citra Kota Surakarta

\section{Metode}

Penelitian ini dapat digolongkandalam penelitian dengan paradigma konstruktif. Penelitian yang menggunakan paradigma konstruktifmemandang realitas sosial sebagai sesuatu yang utuh, kompleks, dinamis, penuh makna, dan hubungan gejala bersifat interaktif (Sugiyono, 2013: 12). Penelitian dengan paradigma konstruktif akan menggunakan metode kualitatif, tujuannya adalah untuk menemukan data-data yang berserakan, selanjutnya dikonstruksikan dalam suatu tema yanglebih bermakna dan mudah dipahami(Sugiyono, 2013: 12).

Pendekatan kualitatif dideskripsikan sebagai penelitian yang bersifat perspektif emic artinya memperoleh data sebagaimana seharusnya, bukan berdasarkan apa yang dipikirkan oleh peneliti, tetapi berdasarkan sebagaimana adanya yang terjadi di lapangan, yang alami, dirasakan, dan dipikirkan oleh partisipan atau sumber data. 
Peneliti akan akan menggali data awal mengenai sumber-sumber pustaka tentang city branding strategi sebagai teori yang utama yang digunakan pada penelitian ini. Identifikasi citra kota akan digunakan sebagai teori pendukung Teori city branding strategy harus dipahamisebagai proses komunikasi interaktif karena merupakansistem strategis yang komprehensif dan signifikan, sehingga city branding strategy memiliki karakteristik kolektif yang memerlukan pertimbanganmeliputi kompleks dan beragam poin sendiri.City brand meliputi berbagai unsur seperti atribut kota,lingkungan, politik, ekonomi, sosial dan budaya. Unsur-unsur ini datang bersama-samauntuk membentuk identitas merek kota. Pada dasarnya citra merek kota yang dibentuk berdasarkanpada objek atau pengalaman dari masyarakat sekitar dan pengunjung kota tersebut.Melalui metode ini, citra kotaakhirnya dibentuk dan dibangun (Jiyoung, 2010: 62).

\section{Pembahasan}

\section{City Branding}

Menurut Keith Dinnie (2011) City branding adalah tentang mengidentifikasi satu set brand attributes yang dimiliki sebuah kota sesuai urutan untuk membentuk sebuah dasar yang digunakan untuk menghasilkan persepsi positif dari banyak audiences. Anholt dalam Moilanen \& Rainisto (2009: 7) mengartikan city branding sebagai bentuk manajemen citra suatu tujuan melalui inovasi strategis serta kordinasi ekonomi, komersial, sosial, kultural, dan peraturan pemerintah. City branding akhirnya berkembang dalam berbagai pendekatan. Banyak terdapat pembahasan mengenai city branding dari berbagai bidang keilmuan. Rainisto (2003: 25) menjelaskan kerangka teori place branding yang terfokus pada upaya memasarkan kota. Kavaratzis (2004: 66-69) menilai city branding dalam konteks mengkomunikasikan dari citra suatu kota melalui tiga tahapan komunikasi yaitu primer, sekunder dan tersier. Menurut Murfianti (2010) city branding banyak digunakan oleh kota-kota dunia dalam upaya meningkatkan atau merubah citra suatu tempat/wilayah/kota, dengan menonjolkan kelebihan dan keunikan daerah tersebut. Banyak keuntungan yang akan diperoleh jika suatu daerah melakukan City branding, yaitu:

1. Daerah tersebut dikenal luas (high awareness), disertai dengan persepsi yang baik

2. Dianggap sesuai untuk tujuan-tujuan khusus (specific purposes)

3. Dianggap tepat untuk tempat investasi, tujuan wisata, tujuan tempat tinggal, dan penyelenggaraan kegiatan/events.

4. Dipersepsikan sebagai tempat dengan kemakmuran dan keamanan yang tinggi.

Pendekatan city branding dilakukan berdasarkan penyatuan komunikasi melalui enam saluran yang kemudian membentuk city branding hexagon (Anholt, 2003), yaitu: 
1. Turisme dan festival/event

Hal ini sering kali menjadi element city brand dan paling aktif dan diekspresikan secara luas. Menarik pendatang dari pihak swasta dan professional dan ternama, sama halnya dengan event olahraga dan budaya bagi sebuah kota sangat penting bagi ekonomi lokal.

2. Export

Kota biasanya dikenal dari kesuksesan bisnis dan produk brandnya. Hubungan antara sebuah kota dan perusahaan khusus dapat menjadi kuat dan menguntungkan kedua belah pihak.

\section{Kebijakan Pemerintah Kota}

Meskipun jarang dipertimbangkan sebagai element dari strategi city branding, kebijakan dan hubungan pemerintahan kota amat sangat besar pengaruhnya pada komunitas lokal dan eksternal serta pengambil keputusan. Hubungan yang baik dengan bisnis dan insitusi lokal, media lokal dan nasional, pemerintah pusat, kota tetengga serta organisasi internasional dan supra nasional, sangat penting untuk city brand mencapai potensinya secara penuh.

4. Investasi

City brand yang jelas dan pasti akan membantu menarik investasi eksternal, bakat dan bermacam-macam imigran dan sesuai dengan kebutuhannya. Jelas bahwa perusahaan professional akan ditarik ke dalam kota karena berbagai faktor, temasuk kualitas hidup, reputasi masyarakat bisnis, reputasi kreatifitas dan inovasi, skala kesempatan berusaha dan populasi terdidik dengan keahlian.

5. Sejarah, budaya dan peristiwa penting

Setiap kota pastinya memiliki sejarah masing-masing. Bagi beberapa, sejarahnya panjang dan luar biasa, sementara lainnya pendek tetapi tetap menarik. Setiap kota mempunyai hikayat untuk diceritakan tentang dasar dan pembangunannya, warga negara terkenal dan artis dan momen berarti. Sering kali hal-hal tersebut disimbolkan dengan landmark kota seperti asitektur bangunan, teater, stadion, museum, tempat umum, monument, dan fitur alami.

6. Masyarakat

Masyarakat kota merupakan aset terpenting. Kota yang ditinggalkan hanya memiliki nilai arkeologi dan keingintahuan, sementara kota yang diamis dan bersemangat menahan orang yang penuh imajinasi yang menggunakan kreativitas branda dan menarik lainnya untuk tinggal, bekerja, invest, berkunjung dan bermain di sana.

City branding semata-mata bukanlah pekerjaan dari sektor publik, akan tetapi tugas dan kolaborasi dari semua pihak (stakeholders) baik pemerintah kota, pihak swasta, pengusaha dan masyarakat. Ponorogo menggunakan pendekatan melalui sejarah, budaya dan peristiwa penting yaitu kesenian tradisional Reog karena kesenian Reog memiliki peran penting dalam berdirinya Ponorogo. Sebuah kota layaknya sebuah brand harus bersifat fungsional. Dalam membuat sebuah city branding terdapat 
kriteria yang harus dipenuhi, diantaranya atribut yang menggambarkan sebuah karakter, daya tarik, gaya dan personalitas kota (Satria, 2011).

\section{Elemen-elemen Pembentuk Citra Kota}

Citra kota terbentuk dari elemen-elemen pembentuk citra kotanya yang terdiri dari: (lihat Lynch, 1982)

1. Tetenger (Landmark),yang merupakan titik referensi seperti elemen simpul tetapi tidak masuk ke dalamnya karena bisa dilihat dari luar letaknya. Tetenger adalah elemen eksternal yang merupakan bentuk visual yang menonjol dari kota misalnya gunung, bukit, gedung tinggi, menara, tanah tinggi, tempat ibadah, pohon tinggi dan lain-lain. Beberapa tetenger letaknya dekat sedangkan yang lain jauh sampai di luar kota.Tetenger adalah elemen penting dari bentuk kota karena membantu orang untuk mengenali suatu daerah.

2. Jalur (Path), yang merupakan elemen paling penting dalam citra kota. Kevin Lynch menemukan dalam penelitianya bahwa jika identitas elemen ini tidak jelas, maka kebanyakan orang meragukan citra kotanya secara keseluruhan. Jalur merupakan alur pergerakan yang secara umum digunakan oleh manusia seperti jalan, gang-gang utama, jalan transit, lintasan kereta api, saluran dan sebagainya. Jalur mempunyai identitas yang lebih baik jika memiliki tujuan yang besar (misalnya ke stasiun, tugu, alun-alun) serta ada penampakan yang kuat (misalnya pohon) atau ada belokan yang jelas.

3. Kawasan (District),yang merupakan kawasan-kawasan kota dalam skala dua dimensi. Sebuah kawasan memiliki ciri khas mirip (bentuk, pola dan wujudnya) dan khas pula dalam batasnya, orang merasa harus mengakhiri atau memulainya. Kawasan dalam kota dapat dilihat sebagai referensi interior maupun eksterior. Kawasan menpunyai identitas yang lebih baik jika batasnya dibentuk dengan jelas berdiri sendiri atau dikaitkan dengan yang lain.

4. Simpul (Nodes),yang merupakan simpul atau lingkaran daerah strategis, arah atau aktivitasnya saling bertemu dan dapat diubah arah atau aktivitasnya misalnya persimpangan lalu lintas, stasiun, lapangan terbang, dan jembatan. Kota secara keseluruhan dalam skala makro misalnya pasar, taman, square dan lain sebagainya. Simpul adalah suatu tempat orang mempunyai perasaan masuk dan keluar dalam tempat yang sama.

5. Batas atau tepian (Edge), yang merupakan elemen linier yang tidak dipakai atau dilihat sebagai jalur. Batas berada diantara dua kawasan tertentu dan berfungsi sebagai pemutus linier misalnya pantai, tembok, batasan antara lintasan kereta api, topografi dan lain-lain. Batas lebih bersifat sebagai referensi daripada misalnya elemen sumbu yang bersifat koordinasi (linkage). Batas merupakan penghalang walaupun kadang-kadang ada tempat untuk masuk. Batas merupakan pengakhiran dari sebuah kawasan atau batasan sebuah kawasan 
dengan yang lainnya. Demikian pula fungsi batasnya harus jelas membagi atau menyatukan.

Kotler (1993), menyebutkan beberapa faktor yang dapat menentukan citra suatu kota antara lain:

1. Persepsi personal terhadap suatu tempat dapat beragam antara orang yang satu dengan yang lainnya (penduduk asli, pengunjung, pengusaha, investor dan pelancong)

2. Posisi dari tempat tersebut akan mendukung citra yang tercipta

3. Tergantung pada waktu dan dapat berlaku sepanjang waktu.

Selain itu dijelaskan pula bahwa terdapat 3 cara dalam membahasakan citra antara lain:

1. Slogan, tema dan kedudukan

Slogan ini erat kaitannya dengan tagline, dalam hal ini sebuah citra kota akan tersampaikan melalui slogan kota tersebut. Salah satu aspek implementasi dari city branding diwujudkan dalam city slogan, dan setiap kota memiliki tagline tersendiri sebagai representasi dari kota yang bersangkutan.

2. Simbol visual

Simbol visual yang dimaksud disini adalah sebuah logo. Logo sangat berperan penting dalam menghadirkan sebuah citra. Logo menjadi ujung tombak dalam mengkomunikasikan sebuah citra. Logo pada sebuah kota akan identik dengan identitas dari kota tersebut.

3. Peristiwa dan kegiatan, media massa memiliki peran penting melalui ketiganya dalam memunculkan citra suatu kota di mata masyarakat.

\section{Analisis Citra Ponorogo}

\section{Tetenger (Landmark)}

Dari hasil wawancara kepada pengunjung dan penduduk Kabupaten Ponorogo, tetenger yang mencitrakan Ponorogo adalah

a. Gapura Pembatas Kota

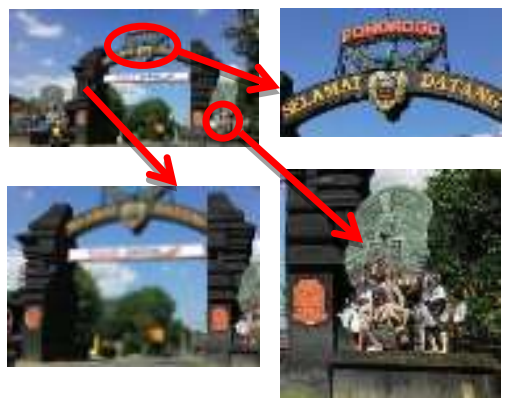

Gambar 1: Gapura pembatas kota Ponorogo dari arah Wonogiri 
Citra yang dihadirkan melalui gapura ini berdasarkan persepsi masyarakat adalah kerajaan Jawa kuno, persepsi tersebut muncul dibenak masyarakat dikarenakan dua gapura yang berwarna hitam yang menyerupai bentuk candi yang terbelah. Bentuk tersebut merupakan replika dari candi bentar yang muncul saat kerajaan Majapahit. Persepsi masyarakat juga terkait dengan bentuk patung-patung Reog yang menghiasi di samping gapura tersebut, maka dari itu persepsi masyarakat menyimpulkan bahwa Ponorogo merupakan dahulunya adalah sebuah Kerajaan yang merupakan lahirnya sebuah kesenian Reog.

Unsur mistis juga terdapat pada gapura tersebut, persepsi masyarakat tersebut dikarenakan warna hitam yang mendominasi gapura tersebut, warna hitam memberikan kesan yang menyeramkan. Persepsi ini didukung juga dengan hadirnya karakter Reog yang berbau mistis, hal ini didasari pengalaman masyarakat dalam menyaksikan sebuah pertunjukan Reog yang tidak sedikit para pemain Reog yang mengalami kerasukan.

\section{Jalur (Path)}

Dari hasil wawancara kepada pengunjung dan penduduk Kabupaten Ponorogo, jalur yang mencitrakan Ponorogo adalah Jalan Ponorogo-Geger

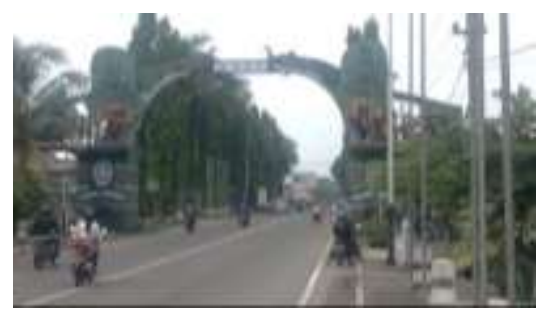

Gambar 2: Jalan Ponorogo-Geger

Jalan ini menjadi penghubung antara Ponorogo dan Madiun. Jalan Ponorogo-Geger ini merupakan jalan utama para wisatawan yang berasal dari arah timur. Dalam menghadirkan citra Ponorogo jalan ini berperan penting karena merupakan jalan utama untuk memasuki Ponorogo selain itu pada jalan ini juga terdapat gapura kota yang merepresentasikan identitas dari Ponorogo.

Jalan ini memiliki citra tersendiri bagi pengunjung dan penduduk sekitar. Citra yang hadir berdasarkan persepsi masyarakat adalah kedamaian dan keindahan kota Ponorogo. Persepsi tersebut dikarenakan jalan ini berkesan sepi dan tenang selain itu banyak terdapat pohon-pohon yang berjajar di sepanjang jalan sehingga berkesan Ponorogo merupakan kota yang asri. Jalan ini berperan penting dalam menghadirkan citra Ponorogo karena merupakan jalan utama untuk memasuki Ponorogo selain itu pada jalan ini juga terdapat gapura kota yang merepresentasikan identitas dari Ponorogo. 


\section{Kawasan (District),}

Dari hasil wawancara kepada pengunjung dan penduduk Kabupaten Ponorogo, kawasan yang mencitrakan Ponorogo adalah alun-alun Ponorogo

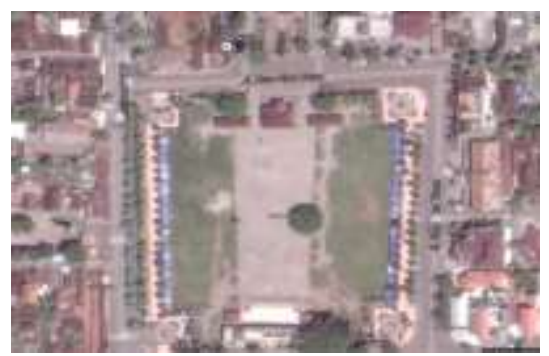

Gambar 3: Alun-alun Ponorogo

Kawasan ini mencitrakan Ponorogo sebagai kota yang dahulunya hutan dan terdapat banyak singa berdasarkan persepsi pengunjung. Hal itu dikarenakan patung-patung singa yang berada pada setiap ujung alun-alun tersebut. Patung-patung tersebut sesungguhnya merupakan sebuah representasi dari salah satu karakter Reog Ponorogo yaitu singo barong. Bagi penduduk sekitar yang mengetahui sejarahnya mempersepsikan alun-alun ini sebagai pusat digelarnya festival Reog nasional. Hal ini Iha yang membuat citra Ponorogo dikenal sebagai Kota Reog.

\section{Simpul (Nodes)}

Dari hasil wawancara kepada pengunjung dan penduduk Kabupaten Ponorogo, simpul yang mencitrakan Ponorogo adalah Alun-alun Ponorogo

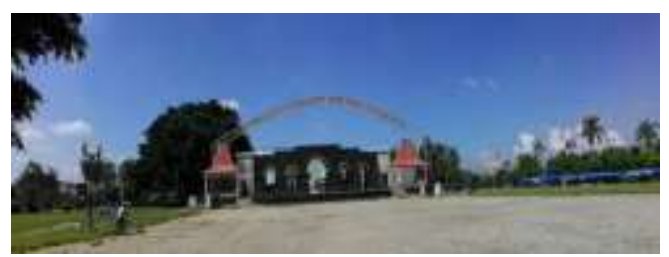

Gambar 4: Alun-alun Ponorogo

Simpul pada Ponorogo yaitu alun-alun Ponorogo yang menjadi pusat segala aktifitas yang melibatkan seluruh warga Ponorogo. Alun-alun ini suatu tempat dimana orang mempunyai perasaan masuk dan keluar dalam tempat yang sama. Hal ini dikarenakan oleh patung-patung yang berada disetiap sudutnya. Kawasan ini mencitrakan Ponorogo sebagai kota budaya, persepsi ini muncul dikarenakan alunalun Ponorogo adalah tempat digelarnya festival Reog nasional.

\section{Batas atau tepian (Edge),}

Dari hasil wawancara kepada pengunjung dan penduduk Kabupaten Ponorogo, batas yang mencitrakan Kabupaten Ponorogo adalah gapura pembatas Ponorogo-Wonogiri 


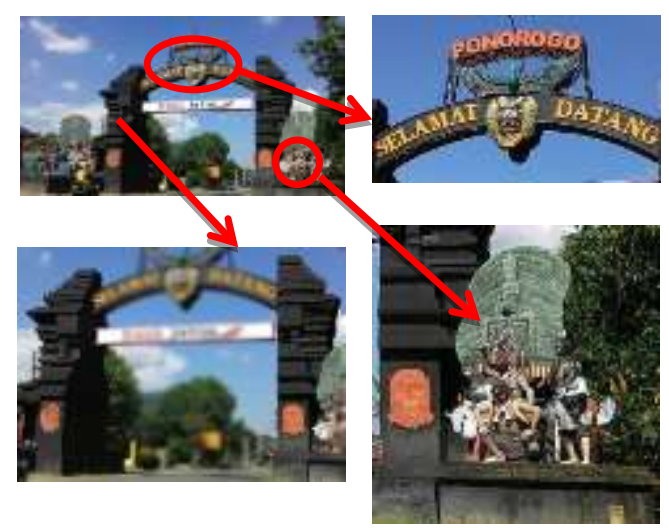

Gambar 5: Gapura pembatas kota Ponorogo dari arah Wonogiri

Citra yang dihadirkan melalui gapura ini berdasarkan persepsi masyarakat adalah kerajaan Jawa kuno, persepsi tersebut muncul dibenak masyarakat dikarenakan dua gapura yang berwarna hitam yang menyerupai bentuk candi yang terbelah. Bentuk tersebut merupakan replika dari candi bentar yang muncul saat kerajaan Majapahit. Persepsi masyarakat juga terkait dengan bentuk patung-patung Reog yang menghiasi di samping gapura tersebut, maka dari itu persepsi masyarakat menyimpulkan bahwa Ponorogo merupakan dahulunya adalah sebuah Kerajaan yang merupakan lahirnya sebuah kesenian Reog.

Unsur mistis juga terdapat pada gapura tersebut, persepsi masyarakat tersebut dikarenakan warna hitam yang mendominasi gapura tersebut, warna hitam memberikan kesan yang menyeramkan. Persepsi ini didukung juga dengan hadirnya karakter Reog yang berbau mistis, hal ini didasari pengalaman masyarakat dalam menyaksikan sebuah pertunjukan Reog yang tidak sedikit para pemain Reog yang mengalami kerasukan.

Selain bentuk fisik yang dapat membahasakan citra, dijelakan pula bahwa terdapat tiga cara dalam membahasakan citra antara lain:

\section{Slogan}

Slogan Ponorogo yang berbunyi "Manunggale Cipto, Roso, Karso Agawe Rahayuning Bumi Reog" terdapat pada Pendopo agung yang berada di kawasan alun-alun Ponorogo.

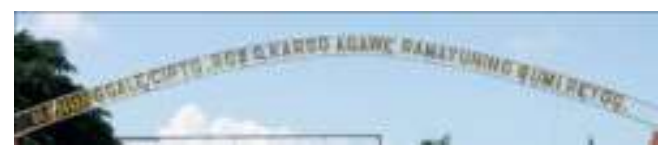

Gambar 6: Slogan yang terdapat pada pendopo agung Ponorogo

Slogan Ponorogo bila dalam bahasa Indonesia adalah "Kesatuan Cipta, Rasa, Karsa UntukKelestarian Bumi Reog" maksud dari slogan ini yaitu ingin menciptakan kelestarian di tanah Reog, tanah Reog disini dimaksudkan yaitu Ponorogo. 
Pemerintah Ponorogo menghadirkan identitas kotanya melalui slogan ini, hal ini yang dapat menghadirkan citra Ponorogo adalah Kota Reog.

2. Simbol visual

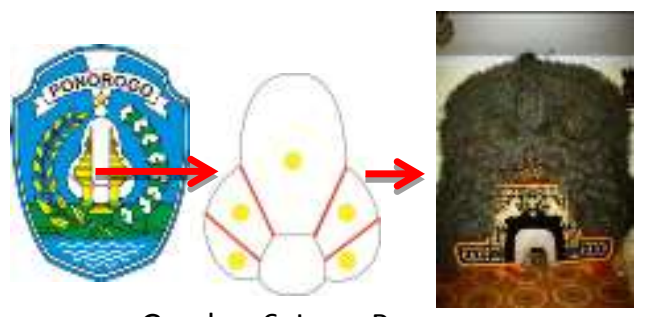

Gambar 6: Logo Ponorogo.

Pada simbol visual yaitu logo Ponorogo juga terlihat penampang Reog sebagai salah satu bagian dari logo tersebut. Penampang Reog melambangkan kesenian asli dan sejarah besar Reog yang ditimbulkan oleh kerajaan-kerajaan lama Ponorogo (Kelana Sewandana) yang mengandung kepahlawan (heroik). Jalur lima (lingkaran berwarna kuning) dan trap empat (garis berwarna merah), mengesankan angka 45 dari tahun 1945 yang bersejarah, yakni tahun kejayaan dan lahirnya proklamasi Kemerdekaan RI.

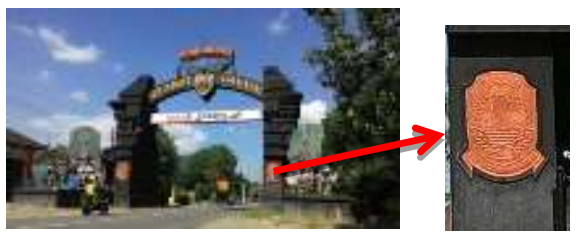

Gambar 6: Logo Ponorogo yang terdapat pada gapura pembatas kota.

Simbol visual Ponorogo yang terdapat pada gapura pembatas kota tersebut tidak dapat menghadirkan citra Ponorogo secara maksimal, hal tersebut dikarenakan simbol visual tersebut diwarnai tidak sesuai dengan simbol yang aslinya, selain itu peletakan dan ukurannya pada gapura diatas tidak sesuai sehingga tidak mendapatkan perhatian dari masyarakat.

3. Peristiwa dan kegiatan dimana media massa memiliki peran penting melalui ketiganya dalam memunculkan citra suatu kota di mata masyarakat.

Festival Grebeg Suro, festival ini adalah acara tahunan yang diadakan oleh pemerintahan Kabupaten Ponorogo. Acara tradisi kultural masyarakat Ponorogo dalam wujud pesta rakyat. Seni dan tradisi yang ditampilkan meliputi Festival Reog Nasional, Pawai Lintas Sejarah dan Kirab Pusaka, dan Larungan Risalah Doa di Telaga Ngebel. Grebeg suro merupakan acara tahunan yang dirayakan setiap tanggal 1 Muharram (1 Suro pada tahun Jawa). Acara ini merupakan kegiatan awal dalam menyongsong Tahun Kunjungan Wisata Jawa Timur setiap tahun.

Rangkaian Grebeg Suro di antaranya, prosesi penyerahan pusaka ke makam bupati pertama Ponorogo. Kemudian disusul pawai ratusan orang menuju pusat kota dengan menunggang bendi dan kuda yang dihiasi. Berikutnya akan ada Festival Reog Nasional di alun-alun kota. Saat itu puluhan grup Reog di Jawa Timur bahkan dari 
Kutai Kartanagara, Jawa Tengah, Balikpapan, dan Lampung akan turut tampil memeriahkan acara tahunan ini. Sejarah diadakannya Grebeg Suro di Kabupaten Ponorogo adalah adanya kebiasaan masyarakat pada malam 1 Suro yang mengadakan tirakatan semalam suntuk dengan mengelilingi kota dan berhenti di alun-alun Ponorogo. Pada tahun 1987 Bupati Soebarkah Poetro Hadiwirjo melihat fenomena ini dan melahirkan gagasan kreatif untuk mewadahi kegiatan mereka dengan kegiatan yang mengarah pada pelestarian budaya. Sebab ditengarainya minat para pemuda terhadap kesenian khas Ponorogo mulai luntur, untuk itu diadakanlah Grebeg Suro dan memasukkan Reog didalamnya. Seni dan tradisi yang ditampilkan meliputi Festival Reog Nasional, Pawai Lintas Sejarah dan Kirab Pusaka, dan Larungan Risalah Doa di Telaga Ngebel.

Dari kegiatan inilah citra terhadap Kabupaten Ponorogo dapat tersampaikan kepada masyarakat luas. Kegiatan yang mengusung tema utama pelestarian terhadap Reog ini dapat mengantarkan sebuah persepsi kepada masyrakat bahwa Kabupaten Ponorogo adalah Kota Reog.

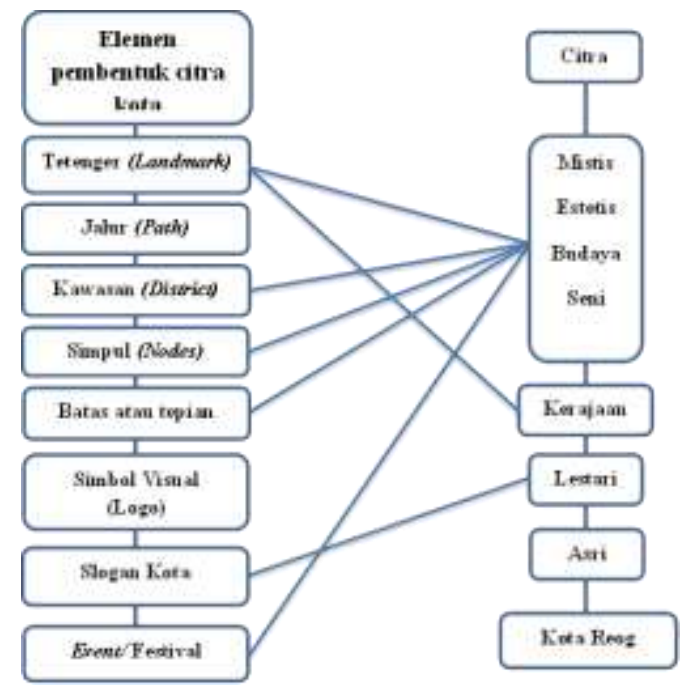

Gambar 7: Diagram analisis citra kota Ponorogo.

Gambar 7 menjelaskan citra Ponorogo berdasarkan persepsi masyarakat akan elemen-elemen pembentuk citra kota. Keywords diatas menjelaskan tentang citra Ponorogo yang mengesankan bahwa Ponorogo merupakan kerajaan pada jaman dahulu dan tempat lahirnya sebuah kesenian Reog. Kesenian tradisi Reog diinterpretasi oleh masyarakat sebagai sebuah kesenian yang mengandung daya magis sehingga menimbulkan kesan mistis pada benak masyarakat. Kesan tersebut muncul karena pembangunan patung-patung yang berfungsi sebagai pembentuk citra didominan warna hitam sehingga memberikan kesan yang menyeramkan. Masyarakat sendiri kurang memahami tentang makna dan nilai yang terkandung pada kesenian Reog. 
Citra Ponorogo sebagai kota yang asri dan lestari dikarenakan oleh jalan yang tidak macet, banyaknya pepohonan di sepanjang jalanPonorogo dan slogan kota yang mencitrakan akan kelestarian Reog Ponorogo. Kesan Ponorogo sebagai kota budaya dan seni tampak pada setiap elemen estetis pembentuk kotanya. Elemen-elemen tersebut berupa patung-patung kesenian tradisional Reog, selain itu kesan Ponorogo sebagai kota budaya terbentuk karena festival Grebeg Suro yang diadakan setiap tahunnya. Pada festival ini diadakan serangkaian kegiatan adata budaya Ponorogo seperti larung sesaji di telaga Ngebel dan festival Reog nasional.

Berdasarkan citra-citra yang dipersepsikan oleh masyarakat peneliti dapat menyimpulkan bahwa dari citra Ponorogo adalah Kota Reog. Reog merupakan sebuah kesenian dari sebuah kebudayaan Jawa Panaragan dan ada sejak jaman kerajaan Jawa Majapahit selain itu unsur mistis dan estetis dalam Reog sangat kuat. Pelestarian terhadap Reog diwujudkan dalam bentuk sebuah identitas Kota Ponorogo.

Citra Ponorogo sebagai Kota Reog beradasarkan elemen-elemen pembentuk citra yang terdapat pada Kota Ponorogo. Berdasarkan citra tersebut dapat disimpulkan bahwa elemen-elemen pembentuk citra pada Ponorogo dpersepsikan oleh masyarakat tanpa mengetahui makna dan nilai yang sebenarnya. Hal tersebut muncul pada citra Reog yang digunakan sebagai identitas Ponorogo, masyarakat mempersepsikan kesenian Reog sebagai sesuatu yang mistis sehingga hal ini mempengaruhi citra terhadap Kota Ponorogo. Citra yang seharusnya dihadirkan secara positif dibenak masyarakat justru memberikan pandangan negatif terhadap kesenian Reog Ponorogo sebagai identitas kota.

\section{Kesimpulan}

Pemanfaatan kesenian tradisional dalam menghadirkan sebuah citra kota merupakan salah satu upaya untuk melestarikan keberadaan sebuah artefak kebudayaan. Pendekatan melalui budaya dalam menciptakan sebuah strategi branding kota harus disertai dengan kajian-kajian tertentu, agar pengaplikasian budaya tersebut tidak mengurangi nilai-nilai sebuah kebudayaan. Penggunaan artefak kebudayaan seperti kesenian tradisional harus disertai dengan semangat nilai dan makna yang terkandung di dalamnya, sehingga penggunaannya tidak hanya untuk kepentingan estetika saja. Hal tersebut dilakukan agar nilai dan makna pada kesenian tradisional tidak hilang, sehingga identitas dari kesenian tradisional tersebut akan hilang dan posisinya akan sama dengan benda-benda dekoratif lainnya.

Pada penelitian ini, kesenian tradisi Reog menghadirkan citra Kota Ponorogo pada benak masyarakat. Pemanfaatan Reog Ponorogo yang digunakan sebagai elemenelemen pengantar citra Kota Ponorogo. Kesenian Tradisional Reog Ponorogo yang kaya akan sebuah nilai filosofi kehidupan orang Jawa kini hadir dalam bentuk patung, gapura, maupun unsur visual lainnya. Pemanfaatan ini tidak disertai dengan riset dan kajian tentang nilai dan makna yang sebenarnya ada pada Reog Ponorogo, hal ini yang menyebabkan keberadaan patung-patung dan gapura hasil representasi dari Reog hanya bersifat sebagai elemen estetis penghias kota saja, bahkan lebih 
ekstremnya pengunjung maupun penduduk sekitar menganggap hadirnya patungpatung ini memiliki kesan yang mistis.

Melalui observasi dan wawancara kepada pengunjung serta penduduk Ponorogo, peneliti mendapatkan sebuah citra yang dihadirkan melalui elemen-elemen yang berbentuk fisikal pada Kota Ponorogo yaitu Ponorogo dikenal dengan kota yang mistis dengan hadirnya Reog pada kota mereka. Tentu hal ini menjadi sebuah kesalahpahaman dalam merancang sebuah branding kota, karena citra yang hadir kepada masyarakat tidak sesuai dengan yang diharapkan.

Pada dasarnya keberadaan patung dan gapura hasil representasi dari Reog tersebut menarik perhatian bagi masyarakat, akan tetapi dalam benak mereka visual tersebut identik dengan hal yang berbau mistis, hal ini tidak terlepas dari pagelaran Reog itu sendiri, masyarakat memahami dalam sebuah pagelaran Reog itu kental dengan aroma mistis, hal itu hadir ketika sebelum memulai sebuah pertunjukan Reog, terdapat sebuah sesajen dan dupa yang dibakar, belum lagi ketika salah satu anggota pertunjukan tersebut ada yang kerasukan. Hal tersebut yang melekat pada pemikiran masyarakat tentang keberadaan Reog itu sendiri.

Reog Ponorogo adalah warisan artefak sebuah kebudayaan yang kaya akan makna dan nilai yang terkandung didalamnya. Pemaknaan Reog Ponorogo secara tradisi mendapatkan sebuah pengetahuan bahwa Reog Ponorogo adalah sebuah tuntunan hidup pada masyarakat Jawa. Tuntunan tersebut adalah manusia didunia ini hendaknya menjaga hawa nafsu yang mereka miliki dan penjelasan tentang sifat-sifat kepemimpinan yang harus dimiliki oleh manusia.

Reog telah menjadi satu dengan masyarakat Ponorogo, keduanya sudah tidak dapat terpisahkan keberadaannya. Penyebutan Reog Ponorogo juga tidak terlepas dari usaha pemerintah dalam memanfaatkan asset yang mereka miliki sebagai media dalam memasarkan daerahnya. Reog dan Ponorogo merupakan satu tidak dapat dipisahkan, meskipun keduanya berbeda akan tetapi kedua kata tersebut saling mengikat satu sama lain.

Pemanfaatan Reog sebagai sebuah strategi dalam mencitrakan Kota Ponorogo memunculkan sebuah pemahaman Paradoks, tarik menarik antara ilmu tradisi yang tertanam dalam Reog dengan penerapannya dalam ilmu modern yaitu strategi branding kota. Hal ini yang menimbulkan terjadinya kesalahpahaman di benak masyarakat akan citra yang tampak pada Ponorogo. Seharusnya melalui konsep paradoksal ini dapat dilihat sebuah kesenian tradisional memiliki nilai-nilai sebuah tuntunan terhadap para penikmatnya, meskipun kesenian tradisional ini sudah berubah bentuk atau fungsi demi kepentingan konservasi, akan tetapi nilai-nilai yang terkandung didalamnya akan tetap tersampaikan. Hal inilah yang menjadikan kesenian tradisonal kita menjadi sesuatu yang spesial, dalam artian kesenian tradisional kita adalah wujud dari identitas bangsa kita. 


\section{Referensi}

Jiyoung Yoon. 2010.A Conceptual Model for City Branding Based on Semiotics. Brunel University.

Kavaratzis, Mihalis dan Ashworth. 2007. "Marketing the City of Amsterdam. Cities, Vol. 24, No. 1, p. 16-25.

Kavaratzis, Mihalis. 2004.From City Marketing To City Branding: Towards A Theoretical Framework For Developing City Brands. Place Branding, Vol. 1.No. 1.

Kottler, Philip. 1993. Marketing Places : Attractive Investment, Industry, and Tourism to Cities, States, and Nations, The Free Press. Cambridge.

Lynch, J. and de Chernatony, L. 2004. The power of emotion: Brandcommunication in business-to-business markets. Journal of Brand management,Vol.11, (5), pp.403-019

Lynch, K. 1960. The image of the city, London: MIT Press

Lynch, Kevin. 1982. The Image of The City. London: Massachusets Institute of Technology.

Moilanen, Teemu \& Rainisto. 2009. How to Brand Nations, Cities and Destinations, A Planning Book for Place Branding. USA: Palgrave Macmillan.

Sugiyono. 2013. Metode Penelitian Kombinasi (Mixed Method). Bandung: Alfabeta. 